\title{
The Effect of Tungstate and Ethanolamines Added in Tap Water on Corrosion Inhibition of Ductile Cast Iron Pipe for Nuclear Power Plants
}

\author{
Butaek Lim ${ }^{1,2, *}$, Kitae Kim ${ }^{1}$, Hyunyoung Chang ${ }^{2}$, Heungbae Park ${ }^{2}$ and Youngsik Kim ${ }^{1, *(1)}$ \\ 1 Materials Research Centre for Energy and Clean Technology, School of Materials Science and Engineering, \\ Andong National University, 1375 Gyeongdongro, Andong 36729, Korea; kitae1@pyunji.andong.ac.kr \\ 2 KEPCO Engineering \& Construction Company, 269, Hyeoksinro, Gimcheon, Gyeongbuk 39660, Korea; \\ hyjang@kepco-enc.com (H.C.); hbpark@kepco-enc.com (H.P.) \\ * Correspondence: ycando@kepco-enc.com (B.L.); yikim@anu.ac.kr (Y.K.); Tel.: +82-54-421-6472 (B.L.); \\ $+82-54-820-5504$ (Y.K.)
}

Received: 22 October 2020; Accepted: 25 November 2020; Published: 28 November 2020

\begin{abstract}
Cast iron is primarily used in buried piping to transport water in the fire protection system of nuclear power plants; ductile cast iron is generally used for domestic nuclear power plants. In general, the fluid used as fire-extinguishing water in such fire protection systems is tap water, and corrosion inhibitors are not currently added. In this study, the synergistic effect of an adsorption barrier (monoethanolamine) and oxidized film in an environment with a corrosion inhibitor (tungstate) is examined, and the corresponding passivation properties are presented. An immersion corrosion test and electrochemical test in tap water to which only tungstate was added showed suppression of corrosion compared to molybdate at the same concentration. The polarization resistance value of a passivation film in tap water mixed with monoethanolamine and tungstate showed better results than that of the molybdate control. A surface analysis in mixed addition tap water also demonstrated that oxygen ions were sufficiently distributed, including at some spheroidized graphite sites, when tungstate was added compared to molybdate. In addition, the amount of tungsten ions adsorbed on the surface was larger than that of molybdenum ions, and it was confirmed that tungsten ions were evenly distributed over the entire surface.
\end{abstract}

Keywords: ductile cast iron; corrosion inhibitor; tungstate; passivation; adsorption; ethanolamine

\section{Introduction}

Corrosion can be described as a mechanism by which a metal gradually loses its original function and deteriorates through contact with gas or liquid owing to a chemical, biochemical, and/or electrochemical reaction according to changes in the surrounding environment [1]. The main substance that causes corrosion at the inner surface of buried pipes is water $\left(\mathrm{H}_{2} \mathrm{O}\right)$. As the operating time of buried piping in a closed system increases, the prolongation of physical and chemical contact between the inner metal and water increases the likelihood of corrosion. The possibility of such corrosion is determined by temperature, flow rate inside the pipe, etc. In addition, it varies depending on factors including the passivation characteristics of the electrochemical reaction [2]. Buried piping may suffer deterioration not only on the outside (soil effect) but also on the inside (fluid side). Depending on access restrictions (because some pipes have a small diameter), the risk of occurrence of corrosion defects increases preferentially according to the electrochemical reactivity at the interface between the base metal and the internal fluid [3]. In the NUREG-1801 (Generic Aging Lessons Learned Report) $\mathrm{R} 2$, a technical standard related to nuclear power plant license renewal in the US, according to safety 
level and the impact of damage to buried piping, a line for management of the target system is selected, and then an aging management program must be established and periodic inspections must be performed [4,5]. In NUREG-1801, the main buried piping systems that need periodic observation are the component cooling water, service water, condensate transfer, and fire protection systems. In all of these systems, preventing fresh water corrosion damage is an important consideration.

Cast iron is the main material used in buried piping systems to transport water in the fire protection systems of nuclear power plants around the world. In Korean nuclear power plants, ductile cast iron is used, and corrosion inhibitors are not currently added [6]. The mechanisms of corrosion damage in buried pipes in an operational nuclear power plant are more often seen in ductile cast iron pipes than pipes made of carbon steel, and damage also occurs in nuclear power plants that have been operational for about 20 years [7]. In order to inhibit corrosion of carbon steel pipes, nitrates, silicates, molybdate, and hydrazine are mainly used; of these, nitrate is known as the corrosion inhibitor with the best performance [8,9]. Corrosion inhibition studies of nitrate have been conducted for many years. As a result, various types of $\mathrm{Fe}_{2} \mathrm{O}_{3}$ formations and oxide films have been developed, and the inhibitory effects of nitrate over time have been clarified [10-14]. Nitrate is an anodic inhibitor that decreases corrosion current by increasing anodic polarization. It rapidly oxidizes the surface of metals with strong oxidizing power to produce $\mathrm{Fe}_{2} \mathrm{O}_{3}$ [15-17]. Recently, K. T. Kim et al. [18] reported on the mechanism of corrosion inhibition of nitrite ion and its effects on the passivation of carbon steel and ductile cast iron. That study suggested that, in order to have the same level of corrosion resistance, about 100 times more nitrate is required for ductile cast iron compared to carbon steel. Although there have been several studies on the synergistic effect of mixing two corrosion inhibitors, the mechanism of such synergistic effects has not been clearly explained [19-21]. Ethanolamine is a representative organic corrosion inhibitor that has an adsorption-type mechanism. There are three (3) kinds of ethanolamine: Monoethanolamine (MEA), diethanolamine (DEA), and triethanolamine (TEA). All three have a good corrosion inhibition effect [22]. Recently, K. T. Kim et al. [23,24] demonstrated the synergistic corrosion inhibition effect of co-addition of nitrite and the three kinds of ethanolamine in ductile cast iron.

Molybdenum is an alloying element that has a beneficial effect on the pitting resistance of stainless steel. Although pure molybdenum does not form a passivation film, it considerably stabilizes a passivation film when added to an alloy [25-27]. The addition of molybdenum as an alloying element to 304 stainless steel forms an outer oxide layer consisting of $\mathrm{MoO}_{4}{ }^{2-}$ that acts as an anion-rejecting layer that helps prevent ingress of $\mathrm{Cl}^{-}$and $\mathrm{OH}^{-}$ions [28-31]. Based on the above, K. T. Kim and co-authors [32] added molybdate to monoethanolamine with the aim of creating a more environmentally friendly, synergistically effective combination of corrosion inhibitors in ductile cast iron. The authors found that molybdate partially oxidizes the surface of the metal while monoethanolamine adsorbs on the graphite surface, creating a barrier that mitigates galvanic corrosion between the matrix structure.

When tungsten in a metallic state is added to an alloy, such as molybdenum, it greatly improves the corrosion resistance of the alloy and synergistically increases the stability of the passivation film. A previous study investigated the strong passivation characteristics of alloys to which tungsten has been added [33]. In a direct solid-phase reaction, tungsten is directly eluted in an acidic solution to bond with water and form $\mathrm{WO}_{3}$ and the addition of tungstate ion to the solution increases the pitting resistance.

On the other hand, Robertson's comparative analysis and mechanistic study [34] of corrosion inhibitors showed that, although both molybdate and tungstate are non-oxidizing agents compared to chromate and nitrite, they are efficient corrosion inhibitors. As shown by Pryor and Cohen [35], chromate and nitrite, which are strong oxidizing agents, passivate even in deaerated solutions, whereas tungstate and molybdate, which have weak oxidizing power, have properties similar to those of chromate and nitrite in the presence of dissolved air and form a weak film in deaerated solutions.

A study on corrosion inhibition by tungstate in neutral aqueous solutions showed that ions and dissolved oxygen are required in the solution [36]. Given such research on corrosion inhibition by tungstate in distilled water, researchers went on to explain that the sulfide ions are more aggressive, 
as shown by a comparison of chloride and sulfide ions at the adsorption barrier between the metal and the solution interface when tungstate is added to $\mathrm{NaCl}$ and $\mathrm{Na}_{2} \mathrm{SO}_{4}$ solution [37]. Regarding synergy, it has been suggested that a mixed corrosion inhibitor can show a sufficient corrosion inhibition effect at a considerably lower concentration than a single inhibitor alone. However, it has been suggested that there is a related advantage, as the non-oxidizing properties of tungstate indicate that it can be mixed with various organic substances to help inhibit corrosion [38]. Tungstate forms a hydrated oxide film that acts as a passivation layer and provides a barrier for anodic dissolution [39,40]. Practically all organic additives act through adsorption, and the mechanism of corrosion inhibition requires the formation of a mixed oxide film that acts as a barrier to anodic dissolution. Additives that strengthen the oxide film are expected to increase the efficiency of corrosion inhibition. In the present study, tungstate (a type of anodic inhibitor) and ethanolamines (an adsorption inhibitor) in tap water were co-added, and chemical and electrochemical tests were performed. The synergistic effect of co-added inhibitors was elucidated using alternating current impedance measurement and surface analysis.

\section{Materials and Methods}

\subsection{Materials and Corrosive Environment}

Ductile cast iron (KS D4311) [41] was used in this work. Table 1 shows the elemental composition of the experimental alloy. The test solution was tap water (Table 2) with or without inhibitors. Tungstate (as $\mathrm{Na}_{2} \mathrm{WO}_{4}, \mathrm{~T}$ ), monoethanolamine (MEA), diethanolamine (DEA), or triethanolamine (TEA) were added in concentrations on the order of ppm.

Table 1. Elemental composition of the experimental alloys.

\begin{tabular}{ccccccccccc}
\hline \multirow{2}{*}{ Material } & \multicolumn{10}{c}{ Elemental Composition, wt \% } \\
\cline { 2 - 11 } & $\mathbf{C}$ & $\mathbf{M n}$ & $\mathbf{P}$ & $\mathbf{S}$ & $\mathbf{S i}$ & $\mathbf{C u}$ & $\mathbf{M o}$ & $\mathbf{N i}$ & $\mathbf{V}$ & $\mathbf{F e}$ \\
\hline $\begin{array}{c}\text { Ductile Cast } \\
\text { Iron (DCI) }\end{array}$ & 4.008 & 0.173 & 0.022 & 0.026 & 1.528 & 0.023 & 0.028 & 0.059 & 0.016 & balance \\
\hline
\end{tabular}

Table 2. Quality analysis of tap water in Andong city, South Korea.

\begin{tabular}{ccccc}
\hline \multirow{2}{*}{ Tap Water } & \multicolumn{4}{c}{ Quality Analysis } \\
\cline { 2 - 5 } & Residual Chlorine & Turbidity & pH & Bacteria \\
\hline Average & 0.25 ppm & 0.09 NTU & 7.1 & 0 CFU/mL \\
\hline
\end{tabular}

\subsection{Corrosion Tests}

Immersion Corrosion Test: Each specimen was cut to a size of $20 \mathrm{~mm} \times 20 \mathrm{~mm} \times 5 \mathrm{~mm}$ and each surface of the specimen was grinded using 120 grit $\mathrm{SiC}$ paper [42]. Immersion corrosion tests were conducted in a $500 \mathrm{~mL}$ glass flask containing stagnant solution and immersion time was $72 \mathrm{~h}$ at room temperature. After the immersion corrosion test, each specimen was ultrasonically cleaned with acetone and ethyl alcohol. Then, the specimen was dried. The mass loss by weighing the specimens before and after immersion was measured using the electronic balance (OHAUS, PAG214C, Parsippany, NJ, USA) in the order of $0.1 \mathrm{mg}$. Finally, the corrosion rate of the specimen was determined.

Electrochemical Tests: Specimens were cut to a size of $20 \mathrm{~mm} \times 20 \mathrm{~mm}$. The specimens were connected in an electrical circuit and epoxy-mounted. Then, the surface of these specimens was grinded using 600 grit SiC paper [43]. Finally, these specimens were coated with epoxy resin, except for an area of $1 \mathrm{~cm}^{2}$. A polarization test was performed using a potentiostat (Gamry Instruments Inc., Interface 1000, Warminster, PA, USA). The reference electrode was a saturated calomel electrode (SCE), and the counter electrode was $\mathrm{Pt}$ wire. The test solution was deaerated using nitrogen gas purged at a rate of $200 \mathrm{~mL} / \mathrm{min}$ into the solution for $30 \mathrm{~min}$ at $30^{\circ} \mathrm{C}$. The scanning rate was $0.33 \mathrm{mV} / \mathrm{s}$ and the 
potential was scanned from $E_{R}-20 \mathrm{mV}$ to near $1000 \mathrm{mV}(\mathrm{SCE})$. In order to measure $\mathrm{AC}$ impedance at $30{ }^{\circ} \mathrm{C}$, the specimens were grinded using 2000 grit $\mathrm{SiC}$ paper [44]. Then, the specimens were polished using a diamond paste (diameter, $3 \mu \mathrm{m}$ ). The test solution was the same as that used in the polarization test. An electrochemical analyzer (Gamry Instruments Inc., EIS 300, Warminster, PA, USA) was used to measure AC impedance. Before measuring AC impedance, passivation was performed on ductile cast iron at $0 \mathrm{mV}$ (SCE) for $30 \mathrm{~min}$ and EIS test was conducted at open circuit potential (OCP). AC impedance was measured in the range of $10 \mathrm{kHz}$ to $0.01 \mathrm{~Hz}$ (10 points per decade) with an AC voltage amplitude of $10 \mathrm{mV}$. A Mott-Schottky plot at $30^{\circ} \mathrm{C}$ was constructed to determine the semi-conductive properties of the passive film. The specimen preparation procedure was the same as that used in the measurement of AC impedance, and the DC amplitude was $10 \mathrm{mV}$ (peak-to-peak) at an AC frequency of $1580 \mathrm{~Hz}$ [45]. The capacitance was measured at a scan rate of $50 \mathrm{mV} / \mathrm{s}$ and the potential was varied between +1 $\mathrm{V}(\mathrm{SCE})$ to $-1 \mathrm{~V}(\mathrm{SCE})$.

Surface Analysis: The specimen was cut to a size of $20 \times 20 \times 5 \mathrm{~mm}$, and it was grinded with 2000 grit $\mathrm{SiC}$ paper. Then, it was polished with a diamond paste, which was $3 \mu \mathrm{m}$ in diameter. Finally, the specimen was cleaned with alcohol using an ultrasonic cleaner. Ductile cast iron was oxidized in $1 \mathrm{k} \mathrm{ppm}$ monoethanolamine $+1 \mathrm{k} \mathrm{ppm}$ tungstate, $1 \mathrm{k} \mathrm{ppm}$ monoethanolamine $+1.5 \mathrm{k} \mathrm{ppm}$ molybdate, or $100 \mathrm{k} \mathrm{ppm}$ tungstate alone. The immersion process was carried out for $72 \mathrm{~h}$ at room temperature and then the surface was immediately analyzed by Electron Probe Micro Analyzer (EPMA, JEOL, JXA-8530F Plus, Tokyo, Japan).

\section{Results}

First, tungstate was added alone and immersion and electrochemical tests were performed. Figure 1 shows the effect of the addition of the single corrosion inhibitor on the corrosion rate of ductile cast iron (DCI). The corrosion rate of the immersed specimen decreased linearly with increasing tungstate concentration. The corrosion of DCI was inhibited at the concentration of $100 \mathrm{k} \mathrm{ppm}$. Thus, addition of tungstate alone at a high concentration significantly reduced the corrosion rate of DCI compared to addition of molybdate alone, based on data previously reported by K. T. Kim et al. [32]. It is likely that the corrosion rate is relatively high at a low concentration of corrosion inhibitor because the concentration is insufficient to passivate the entire surface of the specimen.

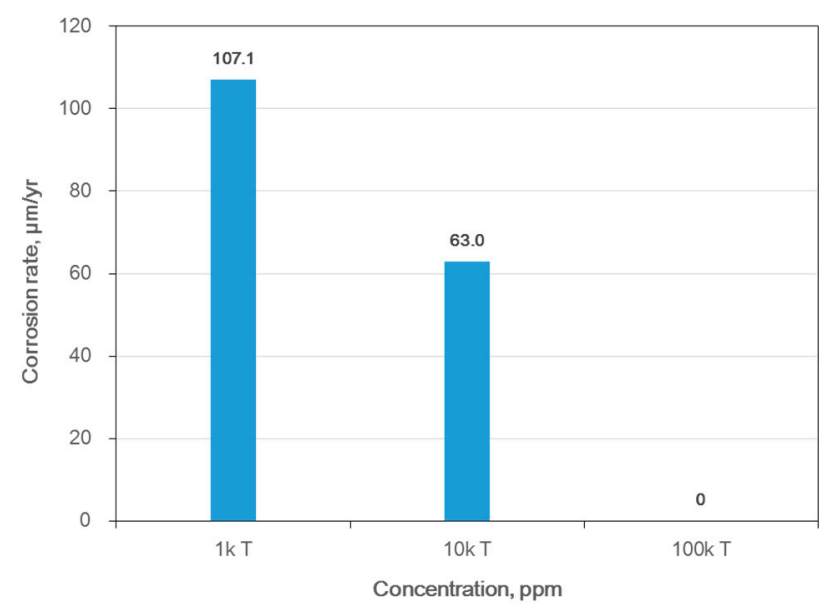

Figure 1. Effect of addition of a single corrosion inhibitor on the corrosion rate of ductile cast iron (DCI) in $[$ tap water $+x$ ppm tungstate $(\mathrm{T})]$ at room temperature.

Figure 2 shows the results of the electrochemical anodic polarization test at concentrations of $1 \mathrm{k}$, $10 \mathrm{k}$, and $100 \mathrm{k} \mathrm{ppm}$ when tungstate was added alone. It was confirmed that passivation occurred to some extent when the concentration was more than $10 \mathrm{k} \mathrm{ppm}$. 


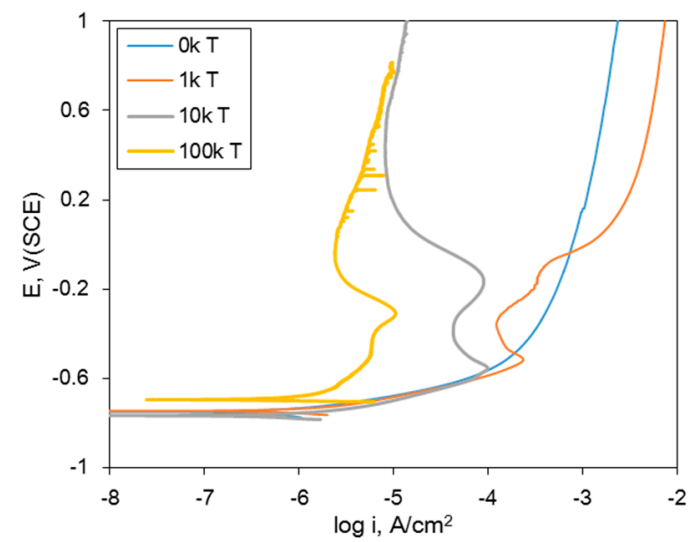

Figure 2. Effect of addition of a single corrosion inhibitor on the anodic polarization curve of DCI in deaerated $[$ tap water $+x$ ppm tungstate $(\mathrm{T})]$ at $30^{\circ} \mathrm{C}$.

Figure 3 presents the passivation current density based on $0 \mathrm{~V}(\mathrm{SCE})$; it is $0.775 \mathrm{~mA} / \mathrm{cm}^{2}$ in the 0 ppm inhibitor case, and also shows the passivation effect of molybdate as a single corrosion inhibitor according to a previous study [32]. In comparison to molybdate, tungstate was associated with a significantly lower current density of $2.43 \times 10^{-6} \mathrm{~A} / \mathrm{cm}^{2}$ at a concentration of $100 \mathrm{k} \mathrm{ppm}$. Even if it is set to an arbitrary value, $0 \mathrm{~V}(\mathrm{SCE})$ has been selected as the point where the passivation characteristic of $100 \mathrm{k}$ tungstate was well expressed. The $\mathrm{pH}$ of $100 \mathrm{k}$ ppm tungstate's solution was measured 10.0, and this increased $\mathrm{pH}$ may affect the corrosion resistance of DCI but it seems to be not significant.

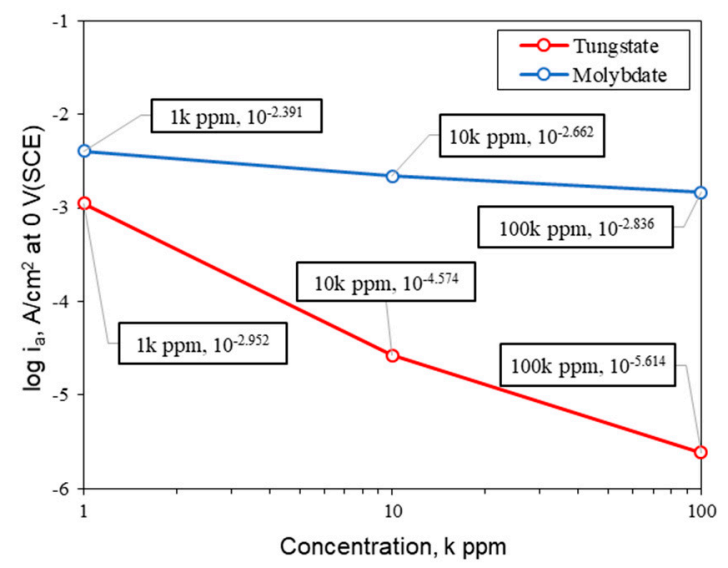

Figure 3. Effect of tungstate and molybdate ions on the anodic current density at 0 V(SCE) obtained from Figure 2.

K. T. Kim et al. [24] studied the efficacy of ethanolamine as a corrosion inhibitor in ductile cast iron. The authors suggested that the passivation properties of monoethanolamine are stable when the concentration of monoethanolamine (added alone) is more than $10 \mathrm{k} \mathrm{ppm}$, and the same results were obtained even when it was mixed with nitrite as a series of MEA $>$ DEA $>$ TEA. Therefore, in this study, triethanolamine (TEA), diethanolamine (DEA), and monoethanolamine (MEA) were mixed with tungstate at the same concentration and the electrochemical anodic polarization test was performed. Figure 4 shows the passivation characteristics upon mixed addition of tungstate and triethanolamine, diethanolamine, and monoethanolamine, respectively. With mixed addition of $1 \mathrm{k} \mathrm{ppm}$ tungstate plus $1 \mathrm{k}$ ppm MEA, the $i_{\text {passive, }}$ passive current density based on $0 \mathrm{~V}(\mathrm{SCE})$ was $2.70 \times 10^{-6} \mathrm{~A} / \mathrm{cm}^{2}$, which was the best passivation characteristic observed. As shown in Table 3, the transpassive potential on the anodic polarization curve of DCI was almost the same for mixed addition of tungstate plus diethanolamine and monoethanolamine. 


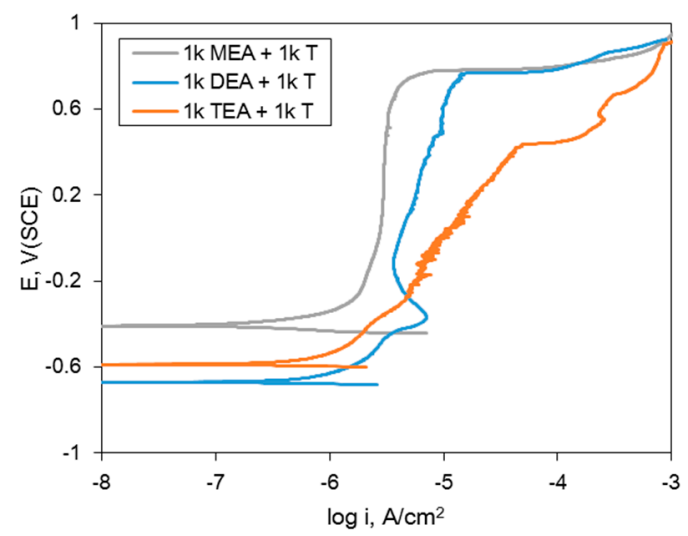

Figure 4. Effect of co-additive corrosion inhibitors on anodic polarization curve of DCI in deaerated [tap water $+1 \mathrm{k} \mathrm{ppm}$ tungstate $(\mathrm{T})+1 \mathrm{k} \mathrm{ppm}$ triethanolamine (TEA) or diethanolamine (DEA) or monoethanolamine (MEA)] at $30^{\circ} \mathrm{C}$.

Table 3. Corrosion factors obtained from Figure 4 according to co-inhibitor composition.

\begin{tabular}{cccc}
\hline Corrosion Factors & $\mathbf{1 ~ k ~ T E A ~ + ~ 1 ~ k ~ T ~}$ & $\mathbf{1 ~ k ~ D E A ~ + ~ 1 ~ k ~ T ~}$ & $\mathbf{1 ~ k ~ M E A ~ + ~ 1 ~ k ~ T ~}$ \\
\hline $\mathrm{E}_{\text {corr }}, \mathrm{V}(\mathrm{SCE})$ & -0.588 & -0.671 & -0.409 \\
$\mathrm{E}_{\mathrm{tr}}, \mathrm{V}(\mathrm{SCE})$ & 0.439 & 0.766 & 0.779 \\
$\mathrm{i}_{\text {passive }}$ at $0 \mathrm{~V}(\mathrm{SCE}), \mathrm{A} / \mathrm{cm}^{2}$ & $9.73 \times 10^{-6}$ & $4.11 \times 10^{-6}$ & $2.70 \times 10^{-6}$ \\
\hline & ${ }^{*} \mathrm{i}_{\text {passive }}$ means the passive current density.
\end{tabular}

Based on the above results, an electrochemical anodic polarization test was carried out in the test solution at a constant concentration of $1 \mathrm{k} \mathrm{ppm}$ of monoethanolamine with tungstate at concentrations of $0.25 \mathrm{k}, 0.5 \mathrm{k}$, and $1 \mathrm{k} \mathrm{ppm}$. The results are shown in Figure 5. The test solution with $1 \mathrm{k} \mathrm{ppm}$ tungstate and $1 \mathrm{k} \mathrm{ppm}$ monoethanolamine showed the best passivation properties, and it had a sufficient corrosion inhibitory effect at considerably lower concentrations than are necessary when either corrosion inhibitor is used alone. To assess the synergistic effect of tungstate as an anodic inhibitor, an immersion corrosion test was conducted based on a study showing that it can be mixed with various organic substances that help inhibit corrosion [38]. The results of mixed addition in tap water are shown in Figure 6. Complete corrosion inhibition was achieved following mixed addition; for comparison, the corrosion rate with the addition of $1 \mathrm{k} \mathrm{ppm}$ tungstate alone was $107.1 \mu \mathrm{m} / \mathrm{yr}$. This is consistent with the results of the anodic polarization curves of ductile cast iron and implies that a mixture of corrosion inhibitors produces a synergistic corrosion inhibition effect at significantly lower concentrations than are necessary for a single inhibitor.

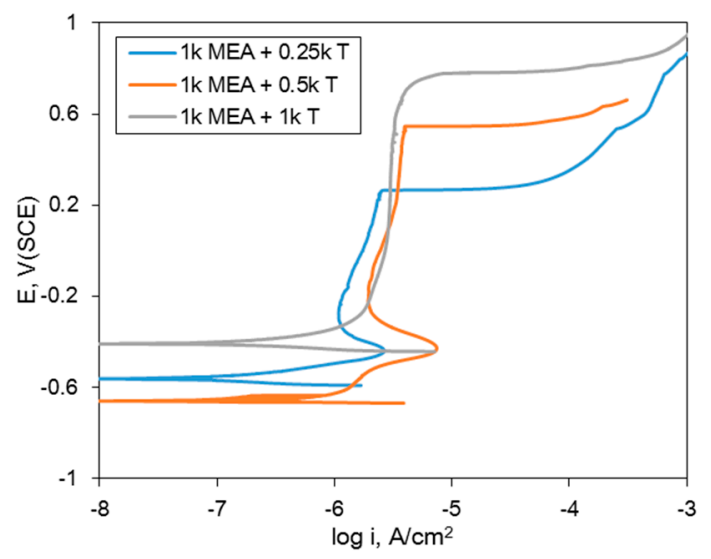

Figure 5. Effect of co-addition of corrosion inhibitors on the anodic polarization curve of DCI in deaerated [tap water $+1 \mathrm{k} \mathrm{ppm}$ monoethanolamine (MEA) $+x \mathrm{ppm}$ tungstate $(\mathrm{T})]$ at $30{ }^{\circ} \mathrm{C}$. 


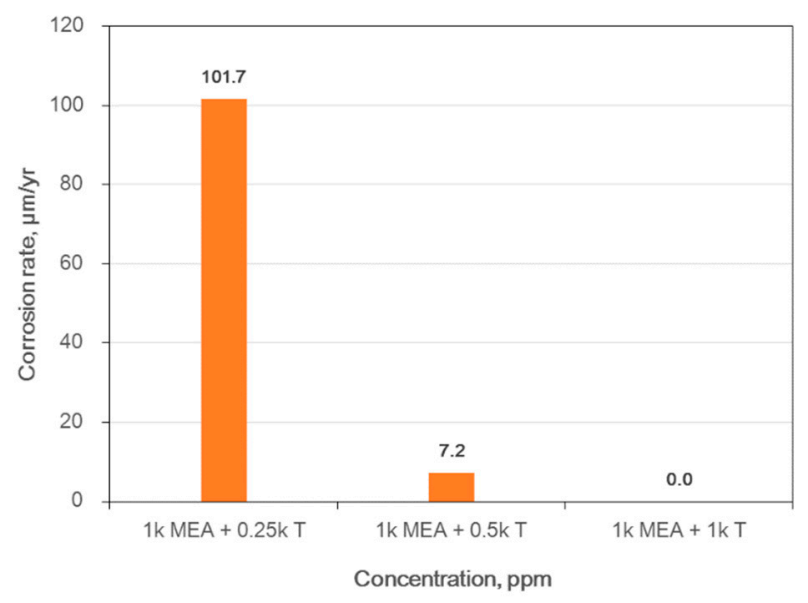

Figure 6. Effect of co-addition of corrosion inhibitors on the corrosion rate of DCI in [tap water $+1 \mathrm{k}$ ppm monoethanolamine (MEA) $+x$ ppm tungstate $(\mathrm{T})]$ at room temperature.

\section{Discussion}

As discussed above, the results of an immersion corrosion test and an electrochemical experiment confirmed that corrosion can be completely inhibited by co-addition of a $2 \mathrm{kppm}$ test solution obtained by mixing tungstate and monoethanolamine. K. T. Kim et al. [32] investigated the synergistic effect of mixed addition of molybdate and monoethanolamine as a corrosion inhibitor in ductile cast iron. Therefore, in this study, measured polarization resistance, semi-conductive properties, and the elemental distribution on the surface when tungstate was added to the solution. Figure 7a shows the effect of corrosion inhibition according to AC impedance in a passivation film based on $0 \mathrm{~V}(\mathrm{SCE})$ on the specimen surface in a deaerated test solution, and Figure $7 \mathrm{~b}$ is a Mott-Schottky plot showing semiconductor characteristics. In general, an electrical equivalent circuit (EEC) that includes a finite number of resistors, capacitors, and inductors cannot adequately model experimental impedance data with the desired approximation [46]. In the electrical equivalent circuit of Figure 8, the first time constant in equivalent circuit was associated with solution resistance $\left(R_{\mathrm{s}}\right)$, constant phase element $\left(C P E_{\text {film }}\right)$, and film resistance $\left(R_{\text {film }}\right)$, and the second time constant in equivalent circuit, double layer capacitance, $C P E_{\mathrm{dl}}$, and charge transfer resistance $\left(R_{\mathrm{ct}}\right)$ were parallel to each other. The summation of $R_{\text {film }}$ and $R_{\mathrm{ct}}$ gives the polarization resistance $\left(R_{\mathrm{p}}\right)[47,48]$. A CPE is often used instead of an ideal double-layer capacitor $\left(C_{\mathrm{dl}}\right)$ to account for the non-ideal capacitance of an actively corroding electrode, and its impedance is given by: $Z_{C P E}=(Y)^{-1}(j \omega)^{-n}$, where $Y$ is the admittance $\left(S \mathrm{~cm}^{-2} \mathrm{~s}^{\mathrm{n}}\right), \omega$ is the angular frequency $\left(\mathrm{rad} \mathrm{s}^{-1}\right), j$ is the imaginary number, $j^{2}=(-1)$, and $n$ is a dimensionless fraction exponent $(-1<n<+1)$. When $n=(+1)$ the $C P E$ is an ideal capacitor, when $n=0$ the $C P E$ is a resistor, when $n=(-1)$ the CPE is an inductor, and finally when $n=0.5$ the CPE is the Warburg admittance [49]. As shown in Figure 7a and Table 4, when the concentration of the mixed corrosion inhibitor is lower, polarization resistance is hardly exhibited. A relatively strong oxide film was formed in the test solution of $2 \mathrm{k} \mathrm{ppm} \mathrm{monoethanolamine} \mathrm{mixed} \mathrm{with} \mathrm{tungstate.} \mathrm{This} \mathrm{implies} \mathrm{that} \mathrm{co-addition} \mathrm{of} \mathrm{ethanolamine}$ and tungstate, a non-oxidizing agent, made the oxide film stronger if added at sufficient concentrations. The Mott-Schottky diagram showing the semiconductor properties in Figure $7 \mathrm{~b}$ shows that, when $1 \mathrm{k}$ ppm monoethanolamine plus $0.25 \mathrm{k} \mathrm{ppm}$ or $0.5 \mathrm{k} \mathrm{ppm}$ tungstate are added to tap water, the p-type and n-type semiconductor characteristics coexist weakly. On the other hand, when the concentration of tungstate was increased to $1 \mathrm{k} \mathrm{ppm}$, only n-type semiconductor properties were shown. At this concentration, a hydrated oxide film formed by the addition of tungstate ion acts as a passivation layer and provides a barrier to anodic dissolution $[39,40]$. In order to inhibit entry of harmful ions to the matrix and movement of $\mathrm{Fe}^{2+}$ ions from the metal surface, tungsten ions as oxide-anions are adsorbed on the outermost side of the hydrated oxide layer [41]; tungstate is needed at sufficient concentrations in tap water to produce this effect. 


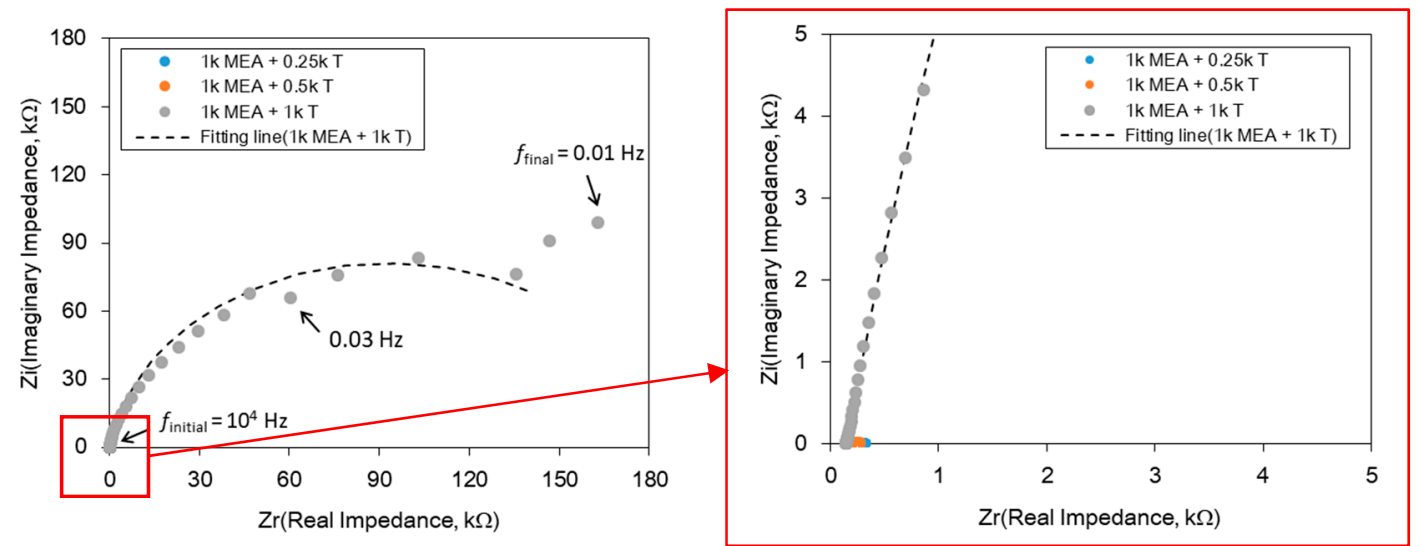

(a)

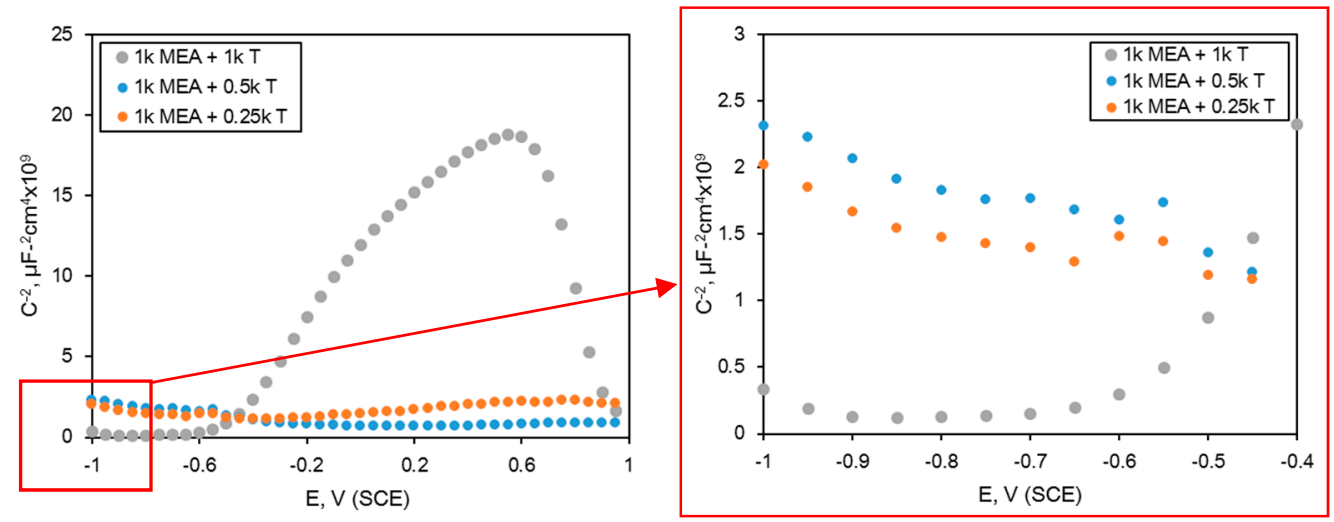

(b)

Figure 7. Effect of co-addition of corrosion inhibitors on the (a) Nyquist plot and (b) Mott-Schottky plot of the passive film formed at $0 \mathrm{~V}(\mathrm{SCE})$ in deaerated [tap water $+1 \mathrm{k} \mathrm{ppm}$ monoethanolamine (MEA) + $x$ ppm tungstate $(\mathrm{T})]$ at $30^{\circ} \mathrm{C}$.

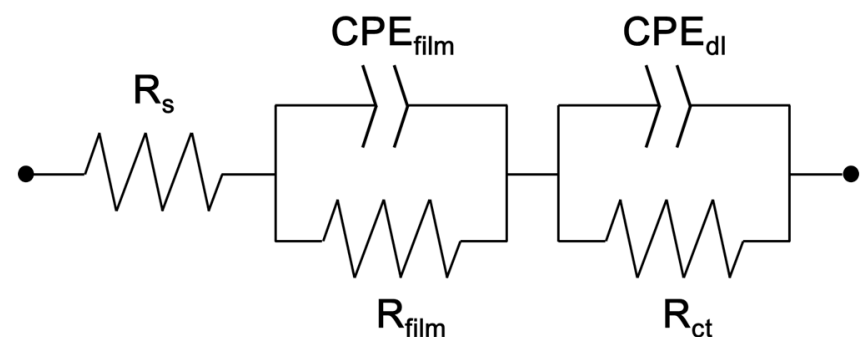

Figure 8. Electrical equivalent circuit used to fit the AC-impedance data.

Table 4. Fitting parameters obtained from Figure 7a according to co-inhibitor composition.

\begin{tabular}{|c|c|c|c|c|c|c|c|}
\hline & $\begin{array}{c}R_{S} \\
\Omega \mathrm{cm}^{2}\end{array}$ & $\begin{array}{r}R_{f i l m} \\
\Omega \mathrm{cm}^{2}\end{array}$ & $\begin{array}{c}Y_{\text {film }} \\
\mathrm{S} \mathrm{cm}^{-2} \mathrm{~s}^{\text {nfilm }}\end{array}$ & $n_{\text {film }}$ & $\begin{array}{c}R_{c t} \\
\Omega \mathrm{cm}^{2}\end{array}$ & $\begin{array}{c}Y_{d l}, \\
\mathrm{~S} \mathrm{~cm} \mathrm{~cm}^{-2} \mathrm{~s}^{\mathrm{ndl}}\end{array}$ & $n_{d l}$ \\
\hline $1 \mathrm{k} \mathrm{MEA}+0.25 \mathrm{k} \mathrm{T}$ & 275.6 & 32.81 & $91.08 \times 10^{-6}$ & 0.397 & 29.04 & $611.4 \times 10^{-6}$ & 0.715 \\
\hline $1 \mathrm{k}$ MEA $+0.5 \mathrm{k} \mathrm{T}$ & 202.7 & 63.31 & $10.03 \times 10^{-3}$ & 0.271 & 51.75 & $153.7 \times 10^{-6}$ & 0.871 \\
\hline $1 \mathrm{kMEA}+1 \mathrm{kT}$ & 142.7 & $185.8 \times 10^{3}$ & $34.80 \times 10^{-6}$ & 0.914 & 9.065 & $69.90 \times 10^{-6}$ & 0.936 \\
\hline
\end{tabular}

Figure 9 shows the polarization resistance $\left(R_{\mathrm{p}}=R_{\mathrm{film}}+R_{\mathrm{ct}}\right)$ of the passivation film when different mixtures of corrosion inhibitors are added to tap water, including the polarization resistance effect of monoethanolamine $1 \mathrm{k}$ ppm plus molybdate $1 \mathrm{k} \mathrm{ppm}$, as done in a previous study [32]. These results 
show that the polarization resistance increased by 21.2-fold when tungstate was added compared to molybdate at the same mixed concentration.

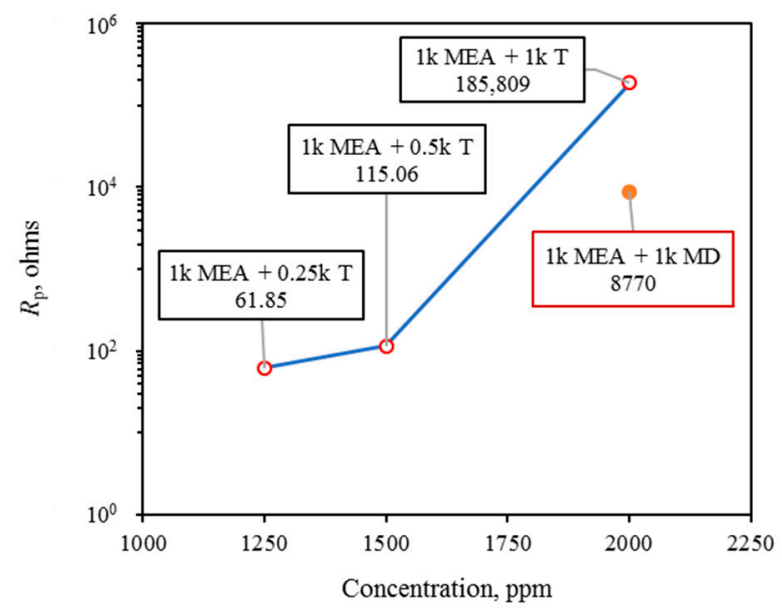

Figure 9. Effect of co-addition of corrosion inhibitors on the polarization resistance of the passive film formed at $0 \mathrm{~V}(\mathrm{SCE})$ in deaerated [tap water $+1 \mathrm{k}$ ppm monoethanolamine (MEA) $+x$ ppm tungstate (T)] at $30^{\circ} \mathrm{C}$ (This figure included $1 \mathrm{k} \mathrm{ppm}$ monoethanolamine (MEA) $+1 \mathrm{k} \mathrm{ppm}$ molybdate (MD) [32]).

As shown in Figure 1, corrosion was completely suppressed when tungstate alone was added to the tap water at a concentration of $100 \mathrm{k} \mathrm{ppm}$. Figure 10 depicts the elemental distribution on the surface of a specimen immersed for $72 \mathrm{~h}$ in test solution with $100 \mathrm{k} \mathrm{ppm}$ tungstate at room temperature. Figure 11 shows the elemental distribution on the surface of a specimen immersed for $72 \mathrm{~h}$ in a test solution containing $1 \mathrm{k} \mathrm{ppm}$ monoethanolamine and $1 \mathrm{k} \mathrm{ppm}$ tungstate at room temperature. This result shows a clean surface with clearly visible spheroidized graphite particles. Fe ions are not visible in the graphite region and, instead, carbon, oxygen, and nitrogen are enriched. The mechanism of corrosion inhibition is that tungstate forms a hydrated oxide film acting as a passivation layer $[39,40]$. At the same time, corrosion inhibition appears to be influenced by monoethanolamine, which aids in adsorption of tungsten ions on the outermost side of the oxide layer [38]. Figure 12 shows the elemental distribution on the surface of a specimen in tap water with monoethanolamine $1 \mathrm{k} \mathrm{ppm}$ plus molybdate $1.5 \mathrm{k} \mathrm{ppm}$, for a total of $2500 \mathrm{ppm}$, which is the condition for complete corrosion inhibition suggested in the previous study [32]. In summary, if monoethanolamine is added to tungstate to inhibit corrosion of ductile cast iron, a synergistic effect can be expected. This synergistic effect by the co-addition of monoethanolamine and tungstate ion was due to the selective adsorption of monoethanolamine on the porous graphite and the passivation of the matrix of cast iron by tungstate ion. Therefore, galvanic corrosion in ductile cast iron can be prevented or mitigated through the interaction of the oxidized film formed by the anodic inhibitor and the adsorption barrier according to the organic inhibitor at relatively low concentrations compared to the high concentrations necessary when a single inhibitor is added alone. 


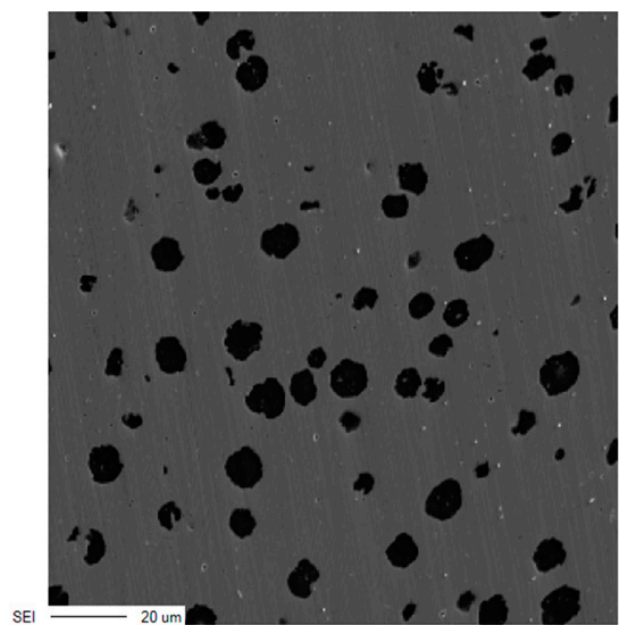

(a)

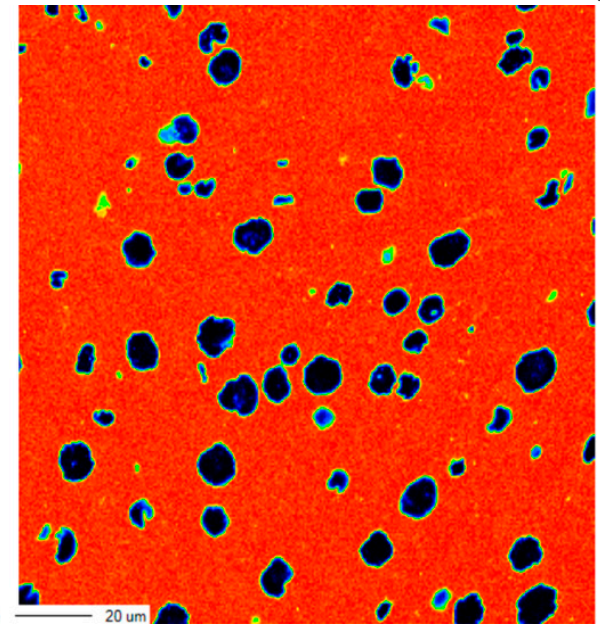

(b)

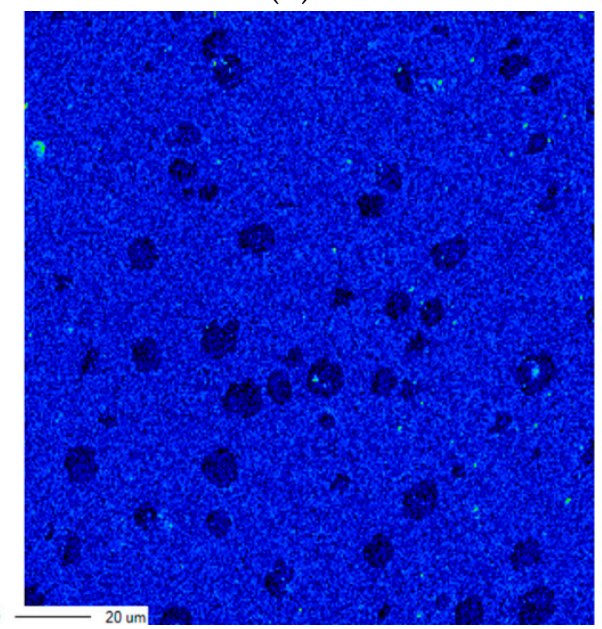

(d)

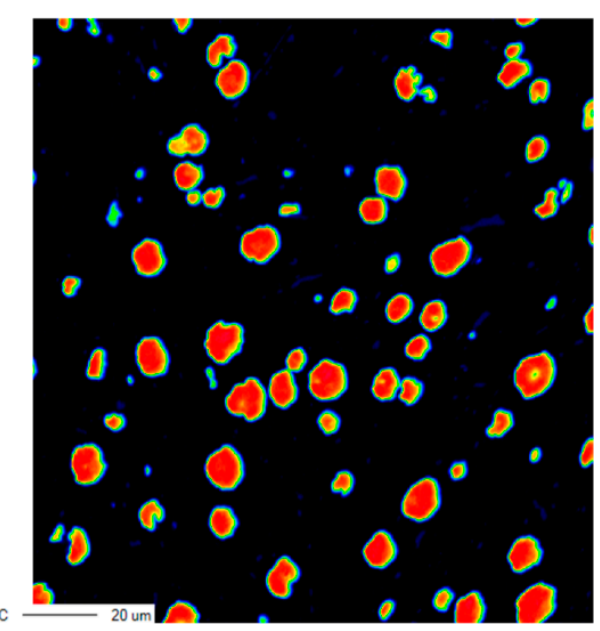

(c)

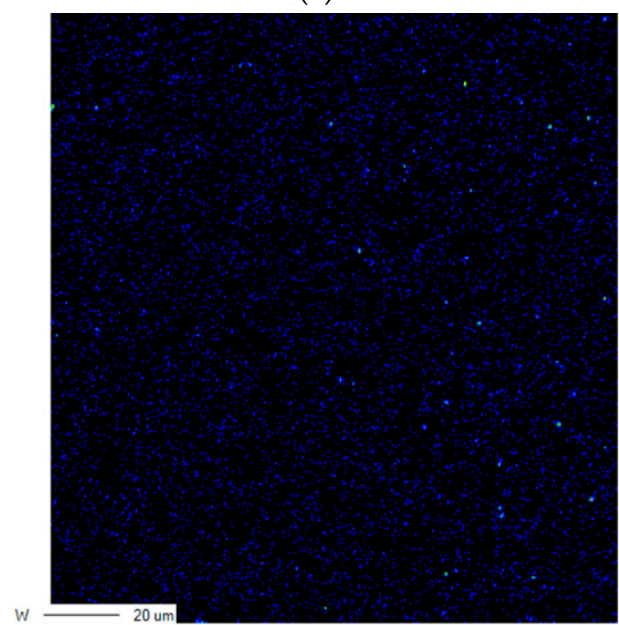

(e)

Figure 10. Elemental distribution analyzed by EPMA on the surface of DCI passivated for $72 \mathrm{~h}$ in tap water with $100 \mathrm{k}$ ppm tungstate at room temperature. (a) SEM image, (b) Fe, (c) C, (d) O, (e) W. 


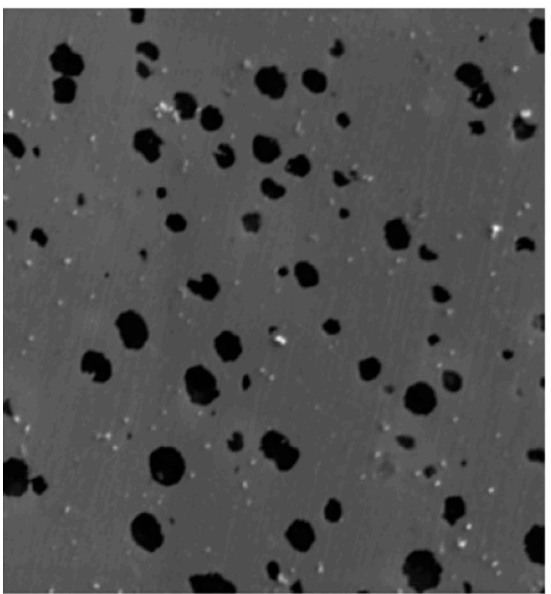

SEI $\longrightarrow 20 \mathrm{um}$

(a)

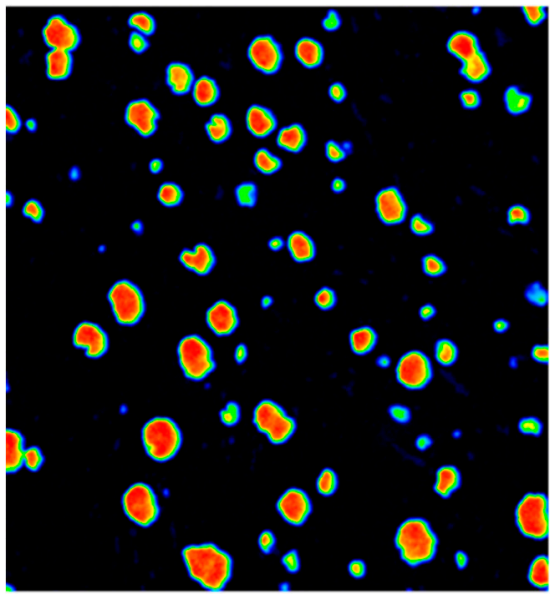

c $\longrightarrow 20 \mathrm{um}$

(c)

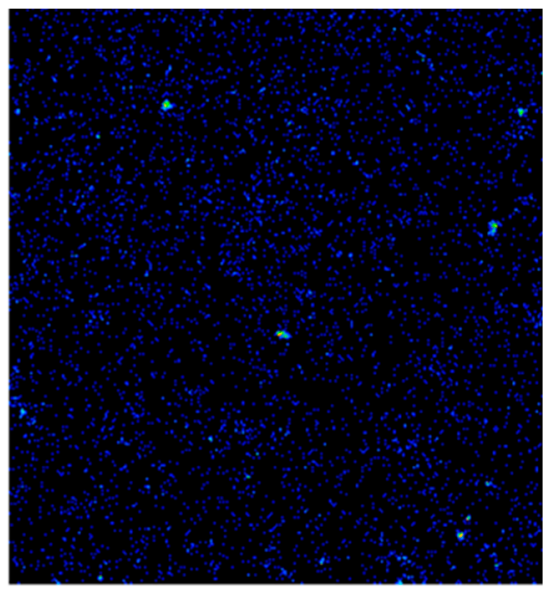

$w \longrightarrow 20 \mathrm{um}$

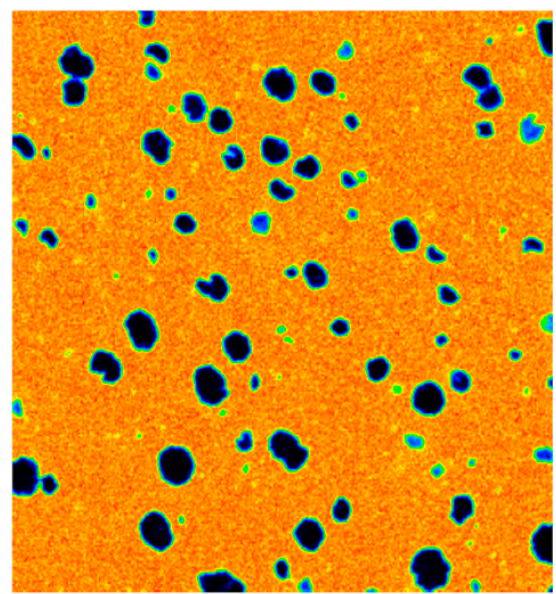

$\mathrm{Fe} \longrightarrow 20 \mathrm{um}$

(b)

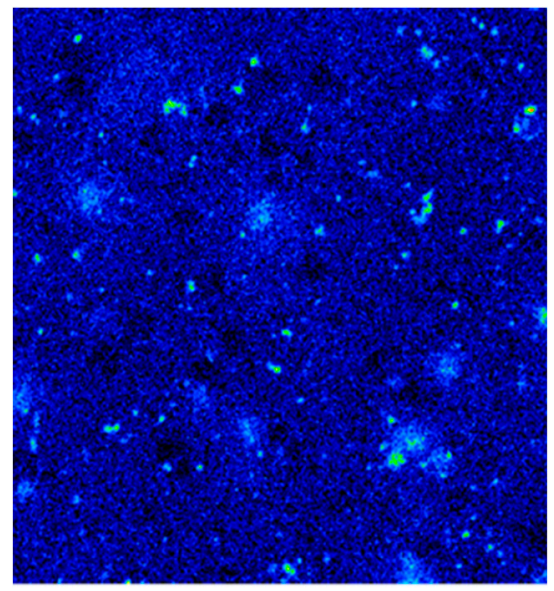

○- $20 \mathrm{um}$

(d)

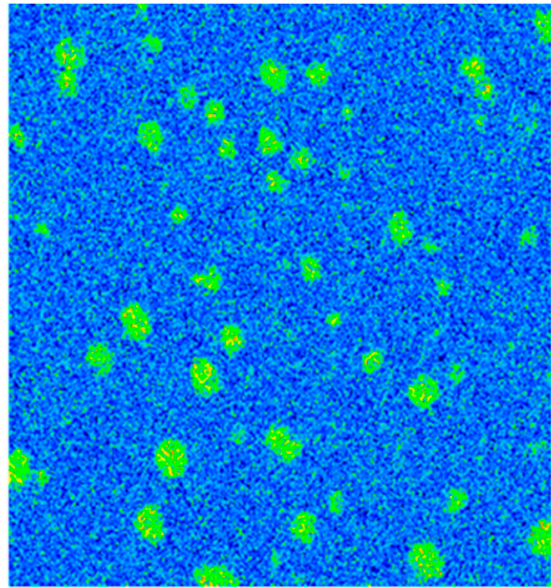

$\mathrm{N} \longrightarrow 20 \mathrm{um}$

(e)

(f)

Figure 11. Elemental distribution analyzed by EPMA on the surface of DCI passivated for $72 \mathrm{~h}$ in tap water with $1 \mathrm{k} \mathrm{ppm}$ tungstate $+1 \mathrm{k}$ ppm MEA at room temperature. (a) SEM image, (b) Fe, (c) C, (d) O, (e) W, (f) N. 


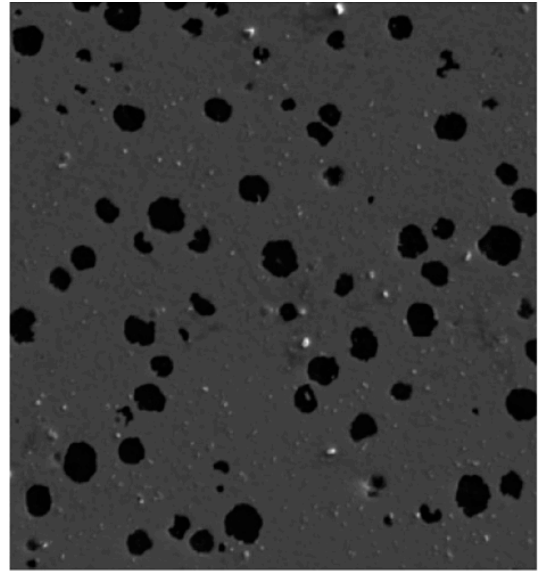

SEI $-20 \mathrm{um}$

(a)

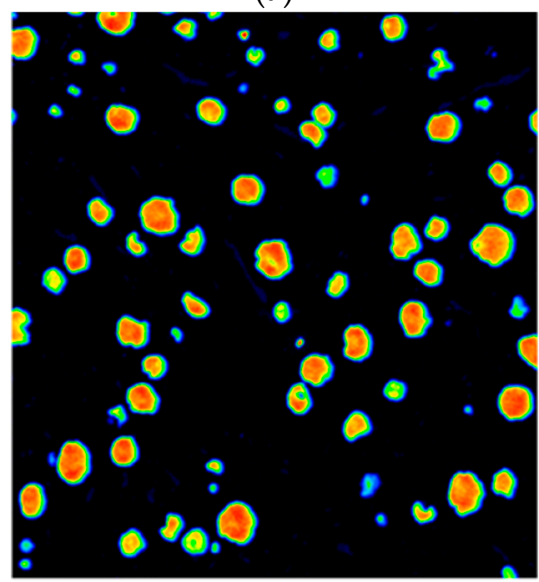

c $\longrightarrow 20 \mathrm{um}$

(c)

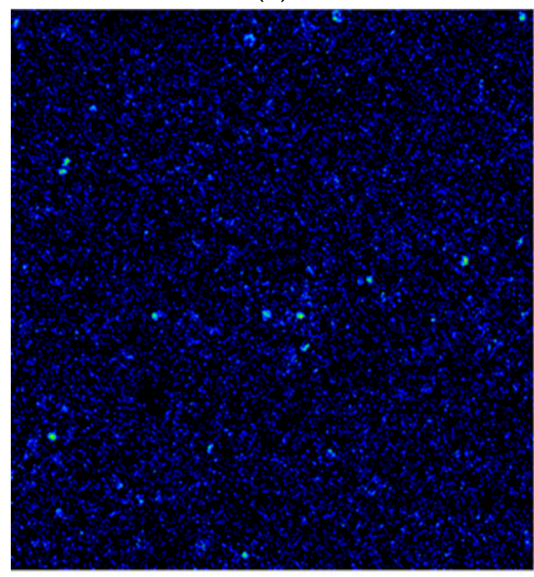

Mo $\longrightarrow 20 \mathrm{um}$

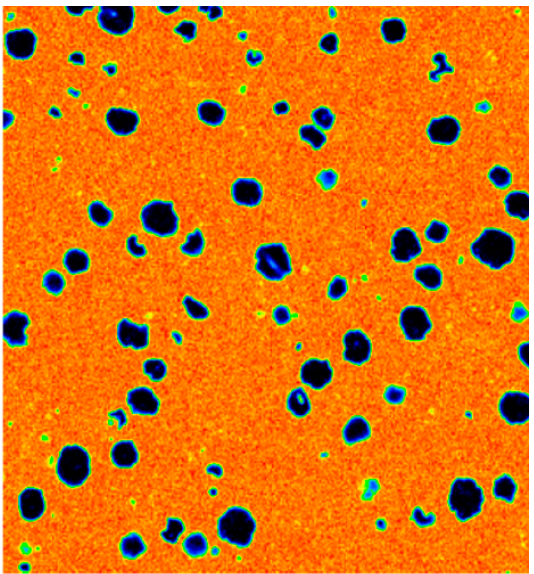

$\mathrm{Fe} \longrightarrow 20 \mathrm{um}$

(b)

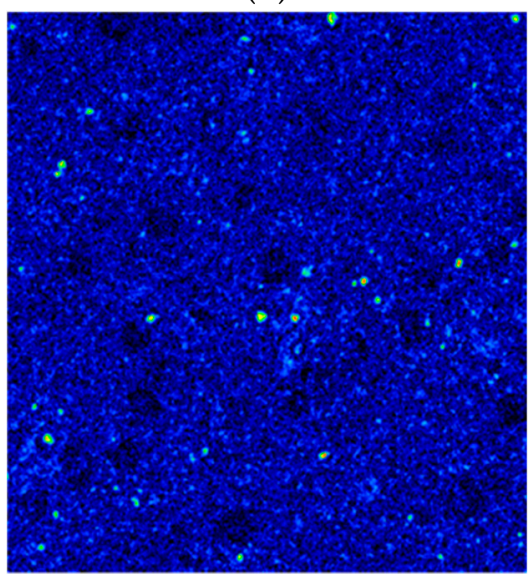

○- $20 \mathrm{um}$

(d)

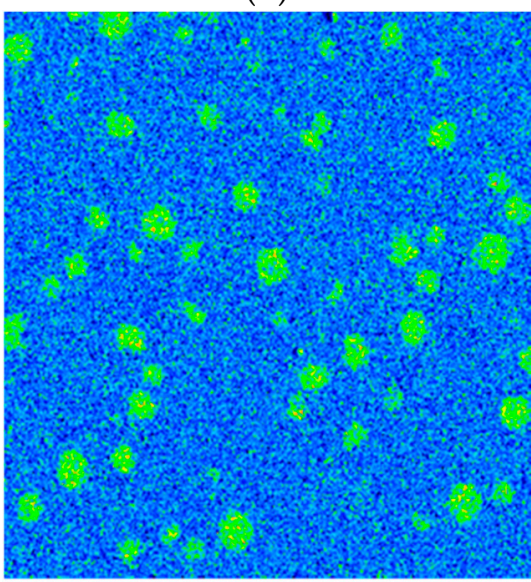

(f)
$\mathrm{N}-20 \mathrm{um}$

(e)

Figure 12. Elemental distribution analyzed by EPMA on the surface of DCI passivated for $72 \mathrm{~h}$ in tap water with $1.5 \mathrm{k} \mathrm{ppm}$ molybdate $+1 \mathrm{kppm}$ MEA at room temperature. (a) SEM image, (b) Fe, (c) C, (d) $\mathrm{O},(\mathbf{e}) \mathrm{Mo},(\mathbf{f}) \mathrm{N}$.

\section{Conclusions}

Cast iron is the main material used in buried piping to transport water in the fire protection systems of nuclear power plants around the world. In general, the fluid used as fire-extinguishing 
water in fire protection systems is tap water. In this study, the synergistic effect of ethanolamine and tungstate in tap water on the corrosion resistance is investigated.

(1) In order to inhibit corrosion of ductile cast iron, a high concentration of tungstate is required when it is used alone, but a synergistic effect is observed when ethanolamines are co-added. Among three kinds of ethanolamines, monoethanolamine addition was very effective.

(2) Immersion and electrochemical tests in tap water with $1 \mathrm{kppm}$ tungstate and $1 \mathrm{k} \mathrm{ppm}$ monoethanolamine showed that corrosion was completely suppressed. Polarization resistance $\left(R_{\mathrm{p}}\right)$ of the passive film formed in the test solution was high due to the formation of oxide film on the matrix of ductile cast iron, and the surface analysis of specimens revealed that oxygen and nitrogen induced from monoethanolamine were mainly detected at porous graphite sites. Therefore, the synergistic effect was due to that tungstate forms an oxide film that acts as a passivation layer by oxidizing the base metal surface, and at the same time, ethanolamine is adsorbed on the spheroidized graphite surface to enhance the corrosion inhibition of ductile cast iron.

Author Contributions: Conceptualization, Y.K.; methodology, B.L. and K.K.; validation, H.C. and Y.K.; investigation, B.L.; data curation, B.L.; writing-original draft preparation, B.L.; writing-review and editing, B.L., K.K. and Y.K.; supervision, Y.K.; funding acquisition, H.P. All authors have read and agreed to the published version of the manuscript.

Funding: This work was supported by the Korea Institute of Energy Technology Evaluation and Planning (KETEP) and the Ministry of Trade, Industry \& Energy (MOTIE) of the Republic of Korea (No. 20171520000350).

Conflicts of Interest: The authors declare no conflict of interest.

\section{References}

1. McCafferty, E. Introduction to Corrosion Science; Springer: New York, NY, USA, 2010; p. 13. [CrossRef]

2. Philip, A.S. Corrosion of Linings and Coatings: Cathodic and Inhibitor Protection and Corrosion Monitoring, Corrosion Engineering Handbook, 2nd ed.; CRC Press: Boca Raton, FL, USA, 2007; pp. 55-57.

3. Clark, B. Recommendations for an Effective Program. to Control. the Degradation of Buried and Underground Piping and Tanks (1016456, Revision 1); EPRI: Palo Alto, CA, USA, 2010.

4. USNRC. Generic Aging Lessons Learned (GALL) Report, NUREG-1801, Rev. 2. In XI.M41 Buried and Underground Piping and Tanks; United States Nuclear Regulatory Commission: Rockville, ML, USA, 2010.

5. USNRC. Inspection Procedure 62002, Inspection of Structures, Passive Components, and Civil. Engineering Features at Nuclear Power Plants; United States Nuclear Regulatory Commission: Rockville, ML, USA, 1996.

6. KHNP. Final Safety Analysis Report for Korean Standard Nuclear Power Plants; Korea Hydro \& Nuclear Power Co., Ltd.: Gyeongju-si, Korea, 1998.

7. KHNP. Equipment Failure Report 06-Hanbit4-1: Hanbit \#4 Firewater Supply Valve Downstream Buried Piping Leakage of Intake Area; Korea Hydro \& Nuclear Power Co., Ltd.: Gyeongju-si, Korea, 2006.

8. Sastri, V.S. Green Corrosion Inhibitors: Theory and Practice, 1st ed.; John Wiley \& Sons, Inc.: Hoboken, NJ, USA, 2011; pp. 216-222.

9. Mohana, K.N.; Badiea, A.M. Effect of sodium nitrite-borax blend on the corrosion rate of low carbon steel in industrial water medium. Corros. Sci. 2008, 50, 2939-2947. [CrossRef]

10. Cohen, M. Inhibition of steel Corrosion by sodium nitrite in water. J. Electrochem. Soc. 1948, 93, 26-39. [CrossRef]

11. Pyke, R.; Cohen, M. Rate of Breakdown and mechanism of nitrite of steel corrosion. J. Electrochem. Soc. 1948, 93, 63-78. [CrossRef]

12. Cohen, M.; Pyke, R.; Marier, P. The effect of oxygen on inhibition of corrosion by nitrite. J. Electrochem. Soc. 1949, 96, 254-261. [CrossRef]

13. Matsuda, S.; Uhlig, H.H. Effect of $\mathrm{pH}$, sulfates, and chlorides on behavior of sodium chromate and nitrite as passivators for steel. J. Electrochem. Soc. 1964, 111, 156-161. [CrossRef]

14. Karim, S.; Mustafa, C.M.; Assaduzzaman, M.; Islam, M. Effect of nitrite ion on corrosion inhibition of mild steel in simulated cooling water. Chem. Eng. Res. Bull. 2010, 14, 87-91. [CrossRef] 
15. Abosrra, L.; Youseffi, M.; Ashour, A.F. Effectiveness of Calcium Nitrite in Retarding Corrosion of Steel in Concrete. Int. J. Concr. Struct. Mater. 2011, 5, 65-73. [CrossRef]

16. Horng, Y.T.; Tsai, Y.L. An Investigation of Mild Steel with Nitrogen-containing Inhibitor in Hydrochloric Acid. Corros. Sci. Tech. 2003, 2, 233-237.

17. Mehra, R.; Soni, A. Inhibition of corrosion of mild steel by nitrite, hydrogen phosphate and molybdate ions in aqueous solution of sodium chloride. Indian J. Eng. Mater. Sci. 2020, 9, 141-146.

18. Kim, K.T.; Chang, H.Y.; Lim, B.T.; Park, H.B.; Kim, Y.S. New Mechanism on Synergistic Effect of Nitrite and Triethanolamine Addition on the Corrosion of Ductile Cast Iron. Adv. Mater. Sci. Eng. 2016, 2016, 4935602. [CrossRef]

19. Okeniyi, J.O.; Popoola, A.P.I.; Loto, C.A.; Omotosho, O.A.; Okpala, S.O.; Ambrose, I.J. Effect of $\mathrm{NaNO}_{2}$ and $\mathrm{C}_{6} \mathrm{H}_{15} \mathrm{NO}_{3}$ Synergistic Admixtures on Steel-Rebar Corrosion in Concrete Immersed in Aggressive Environments. Adv. Mater. Sci. Eng. 2015, 2015, 540395. [CrossRef]

20. Ridhwan, A.M.; Rahim, A.A.; Shah, A.M. Synergistic Effect of Halide Ions on the Corrosion Inhibition of Mild Steel in Hydrochloric Acid using Mangrove Tannin. Int. J. Electrochem. Sci. 2012, 7, 8091-8104.

21. Vishnudevan, M. Synergistic Influence of Nitrite on Inhibition of Mild Steel Corrosion in Chloride Contaminated Alkaline Solution. Iran. J. Mater. Sci. Eng. 2012, 9, 17-27.

22. Carrillo, I.; Valdez, B.; Zlatev, R.; Stoytcheva, M.; Carrillo, M.; Bäßler, R. Electrochemical Study of Oxyanions Effect on Galvanic Corrosion Inhibition. Int. J. Electrochem. Sci. 2012, 7, 8688-8701.

23. Kim, K.T.; Kim, H.W.; Chang, H.Y.; Lim, B.T.; Park, H.B.; Kim, Y.S. Corrosion Inhibiting Mechanism of Nitrite Ion on the Passivation of Carbon Steel and Ductile Cast Iron for Nuclear Power Plants. Adv. Mater. Sci. Eng. 2015, 2015, 408138. [CrossRef]

24. Kim, K.T.; Chang, H.Y.; Lim, B.T.; Park, H.B.; Kim, Y.S. Effect of Ethanolamines on Corrosion Inhibition of Ductile Cast Iron in Nitrite Containing Solutions. Corros. Sci. Tech. 2016, 15, 171-181. [CrossRef]

25. Olsson, C.O.A.; Landolt, D. Passive films on stainless steels-chemistry structure and growth. Electrochim. Acta 2003, 48, 1093-1104. [CrossRef]

26. Brookes, H.C.; Bayles, J.W.; Graham, F.J. Nucleation and growth of anodic films on stainless steel alloys. I. Influence of minor alloying elements and applied potential on passive film growth. J. Appl. Electrochem. 1990, 20, 223-230. [CrossRef]

27. Ameer, M.; Fakry, A.; Heakal, F. Electrochemical behaviour of passive films on molybdenum-containing austenitic stainless steels in aqueous solutions. Electrochem. Acta. 2004, 50, 43-49. [CrossRef]

28. Brooks, A.R.; Clayton, C.R.; Doss, K.; Lu, Y.C. On the Role of Cr in the Passivity of Stainless Steel. J. Electrochem. Soc. 1986, 133, 2459-2465. [CrossRef]

29. Clayton, C.R.; Lu, Y.C. A bipolar model of the passivity of stainless steels-III. The mechanism of $\mathrm{MoO}_{4}{ }^{2-}$ formation and incorporation. Corros. Sci. 1989, 29, 881-898. [CrossRef]

30. Kim, Y.S.; Park, Y.S. A Study on Effects of N Addition on the Passivating Mechanism of Stainless Steels. J. Corr. Sci. Soc. Korea 1989, 18, 97-108.

31. Lu, Y.C.; Clayton, C.R.; Brooks, A.R. A bipolar model of the passivity of stainless steels-II. The influence of aqueous molybdate. Corros. Sci. 1989, 29, 863-880. [CrossRef]

32. Kim, K.T.; Chang, H.Y.; Lim, B.T.; Park, H.B.; Kim, Y.S. Synergistic Effect of Molybdate and Monoethanolamine on Corrosion Inhibition of Ductile Cast Iron in Tap Water. Corros. Sci. Tech. 2017, 16, 31-37. [CrossRef]

33. Bui, N.; Irhzo, A.; Dabosi, F.; Limou Zin-Marie, Y. On the Mechanism for improved passivation by additions of tungsten to austenitic stainless steels. Corrosion 1983, 39, 491-496. [CrossRef]

34. Robertson, W.D. Molybdate and tungstate as corrosion inhibitors and the mechanism of inhibition. J. Electrochem. Soc. 1951, 98, 94-100. [CrossRef]

35. Pryor, M.J.; Cohen, M. The inhibition of the corrosion of iron by some anodic inhibitors. J. Electrochem. Soc. 1953, 100, 203-215. [CrossRef]

36. Abd El Kader, J.M.; El Warraky, A.A.; Abd El Aziz, A.M. Corrosion inhibition of mild steel by sodium tungstate in neutral solution Part 1: Behaviour in distilled water. Br. Corros. J. 1998, 33, 139-144. [CrossRef]

37. Abd El Kader, J.M.; El Warraky, A.A.; Abd El Aziz, A.M. Corrosion inhibition of mild steel by sodium tungstate in neutral solution Part 2: Behaviour in $\mathrm{NaCl}$ and $\mathrm{Na}_{2} \mathrm{SO}_{4}$. Br. Corros. J. 1998, 33, 145-151. [CrossRef]

38. Abd El Kader, J.M.; El Warraky, A.A.; Abd El Aziz, A.M. Corrosion inhibition of mild steel by sodium tungstate in neutral solution Part 3: Co-inhibitors and synergism. Br. Corros. J. 1998, 33, 152-157. [CrossRef] 
39. Celeste, R.A.; Vieira, V.A. Localized corrosion inhibition of stainless steel in pure water by oxyanions tungstate and molybdate. Electrochim. Acta 2004, 49, 2779-2785. [CrossRef]

40. Qiang, S.; Xingqi, Q. Study on the complex of sodium tungstate and urotropine as inhibitors against stainless steel corrosion in the $\mathrm{NaCl}$ solution. Mater. Sci. Forum 2011, 689, 450-454. [CrossRef]

41. Korean Agency for Technology and Standards. KS D4311, Ductile Iron Pipe; Korean Agency for Technology and Standards: Gyeonggi-do, Korea, 2010.

42. ASTM. G31-2009, Standard Practice for Laboratory Immersion Corrosion Testing of Metals; ASTM International: West Conshohocken, PA, USA.

43. ASTM. G5-2004, Standard Reference Test Method for Making Potentiostatic and Potentiodynamic Anodic Polarization Measurements; ASTM International: West Conshohocken, PA, USA.

44. ASTM. G106-2004, Standard Practice for Verification of Algorithm and Equipment for Electrochemical Impedance Measurements; ASTM International: West Conshohocken, PA, USA.

45. Macdonald, D.D. The Point Defect Model for the Passive State. Int. J. Electrochem. Sci. 1992, 139, 3434-3449. [CrossRef]

46. Bastidas, D.M. Interpretation of Impedance Data for Porous Electrodes and Diffusion Processes. Corrosion 2007, 63, 515-521. [CrossRef]

47. Ganash, A.A. Comparative Evaluation of Anticorrosive Properties of Mahaleb Seed Extract on Carbon Steel in Two Acidic Solutions. Materials 2019, 12, 3013. [CrossRef] [PubMed]

48. Sherif, E.M.; Almajid, A.A.; Bairamov, A.K.; Al-zahrani, E. Corrosion of Monel-400 in Aerated Stagnant Arabian Gulf Seawater after Different Exposure Intervals. Int. J. Electrochem. Sci. 2011, 6, 5430-5444.

49. Fajardo, S.; Llorente, I.; Jiménez, J.A.; Bastidas, J.M.; Bastidas, D.M. Effect of Mn additions on the corrosion behaviour of TWIP Fe-Mn-Al-Si austenitic steel in chloride solution. Corros. Sci. 2019, 154, 246-253. [CrossRef]

Publisher's Note: MDPI stays neutral with regard to jurisdictional claims in published maps and institutional affiliations.

(C) 2020 by the authors. Licensee MDPI, Basel, Switzerland. This article is an open access article distributed under the terms and conditions of the Creative Commons Attribution (CC BY) license (http://creativecommons.org/licenses/by/4.0/). 